\title{
worldview
}

\section{WHEN DISSENI BECOMES TREASON: THE CRIMINALITY OF OPINION}

How much criticism can the government of a stable society tolerate? Is there a point beyond which criticism is a crime and dissent is treason? Can a government allow its authority to be questioned and therefore weakened by propaganda and demonstration?

For the Soviet Union these questions were given a fairly definite answer last month when two writers: Andrei Sinyavsky and Yuli Daniel, were tried and sentenced to years of hard labor. Under the pseudonyms of Abram Tertz and Nikolai Arshak, these two writers produced manuscripts which, they judged; could not be published in the present political and cultural climate of Russia. The manuscripts were smuggled out of the country and published abroad. After a public campaign against the two writers, they were tried under a section of the Soviet code that makes it a crime to engage in "agitation or propaganda ... for the purpose of weakening or subverting Soviet authority. . . ?"

Since the "open" trial excluded foreign newsmen, knowledge of what actually took place during the trial has been derived mostly from the acrimonious reports in the Soviet press and radio, and comments in Russian literary journals. The charges were extraordinary, for the authors were accused of grand treason, theft (of literary techniques ), betrayal, anti-Semitism, etc. The trial has obvious similarities to other Soviet trials, and those who have, over the years, maintained their skepticism about Soviet justice will feel justified for some years more.

But there were obvious differences from years past. Neither Sinyavsky nor Daniel were forced to recant or apologize for their"crimes," and among the many figures of stature who criticized and repudiated the trial as unjust were a number of foreign Communist writers and editors. Louis Aragon, the noted French poet and long-time Communist, attacked the trial for establishing "criminality of opinion, a precedent more injurious to the interests of socialism than the works of Sinyavsky and Daniel could be. It is to be feared, indeed, that this type of procedure is inherent in the nature of communism..." Italian, British, Scandinavian and Austrian Party members also rejected the terms of the trial. (It may be worth noting that Herbert Aptheker, a Communist theoretician and one of a trio that made a trip to Vietnam recently, sided with the prosecutors. But one should probably also note that American Communists have not been known for originality or independence.)

The trial and conviction answer some questions that were being asked with a note of calttious optimism in recent years. It is now quite clear that de-Stalinization has its limits, that not everything can be said or written about the Soviet Union by those subject to its control, that political orthodoxy prescribes orthodoxy in all other fields, including the artistic.

It is also clear, however, that in many of its aspects the trial was a Joss for the Soviet Union. Although the, trial was conducted in semisecrecy, it was nevertheless held and its judg. ments publicized. Because of this publicity one of the points made by the prosecution has been thoroughly discredited. For the task of the prosecution was to hold the two writers up as examples, but as isolated examples of writers who had neither sympathetic fellow-writers nor readers. And in this the trial completely failed, both in the Soviet Union where friendly witnesses appeared, and in other countries where critics and readers came to the defense of the writers. The trial also showed that the present Sovict regime was willing to return to some of the most publicized and discredited practices of Stalinism. It supports the views of those who have argned that the Communist regime has built into its very institutions the necessity to inhibit and repress artistic, iritellectual and political freedom.

Yet there are important differences between 
the Russia of Stalin and the Russia of Kosygin. The former was contemptuous of public opinion whether domestic or foreign and cared little for popularity and international marks for good conduct. The Russia of today cannot go all the long way back to those dark days.

When one views the injustice and the foolishness of Soviet action in a case such as this, one car gain a greater appreciation for the tradition of dissent that exists in this country. It often seems to be a spindly, harsh and prickly plant, but then it has had to survive some rather bad native weather. In this country dissent has often been-to change the metaphor-a noisy, ineffcient, disorganized process. But it has kept open possibilities of thought and action that would otherwise bave been foreclosed; it has awakened consciences to moral issues that some of us hardly knew existed; it has indicated goals that have passed from utopian dreams, to unlikely possibilities, to practical necessities.

A time of crisis-and Vietnam is surely a crisis for the American people-tests the value of dissent. But it tests equally well those values, attitudes and actions which dissent calls into question. When mere dissent becomes criminal, it is the state that has been convicted.

\section{SOME STARTLING FIGURES}

According to Joseph Alsop, who writes from Washington, "some pretty peculiar reporting from Vietnam plus a lot of flabby thinking in Washington have combined to produce a mood of defeatism in many quarters of this city." As a remedy he recommended looking at the record.

A tabulation of all the reports from the headquarters of General Westmoreland, he said, leads to some startling figures. From January 1 through March 7, according to Alsop's figures, total enemy losses of all kinds must be numbered in the "tens of thousands," enough to allow the judgment that there has been an "astonishing transformation of the war.".

In the New York Times Magazine of March 6, Bemard Fall also did some figuring. With the additional authorization for the current fiscal year "the per capita expenditure for every captured or killed Viet Cong in 1965 will have come to a substantial $\$ 365,111$."

We don't intend to comment. We simply note that the record does provide some rather startling figures.

J. F.

\section{in the magazines}

A December Commentary article by Theodore Draper-noted in this column in January-which criticized U.S. policy in the Dominican coup of last April, has stimulated debate in the pages of the National Review, and additional comments by Draper himself have appeared in The New Republic and The New Leader.

In the first of two Nattonal heview articles in the February 8 issue, the editor of Latin American Report, a formet U.S. diplomat in Havana who covered the Dominican crisis, marks the original Draper report "a bitchy, nit-picking performance." This writer, Paul D. Bethel, presents evidence to support the validity of press and official statements about the nature and effects of the Dominican coup which Draper had called into question. And he replies to Draper's assertion that there was little substance to the Johnson Administration's charge of Communist manipulation of the revolt.

Mr. Bethel finds "the scream from the left-Liberal corner over U.S. intervention in the Dominican Republic," both "interesting and significant. Most of Mr. Draper's sources" of information, he says, "are wedded to the proposition that the so-called 'democratic Left' in Latin America is the answer to Communist subversion, and to right-wing pressures." But the very fact of "Communist manipulation of the Dominican revolt," which Bethel is able to establish to his satisfaction, "proves that the 'democratic Left' in that country, at least, is politically ineffective."

"The preponderance of evidence is that Juan Bosch and his Dominican Revolutionary Party [PRD] turned to the Communists, voluntarily; to provide the bone and sinew which the PRD sadly lacked. This truth, for our Liberals, is "unthinkable," Bethel contends. "Therefore the Draper reconstruction."

-

In the second National Review article, J. B. Bender ("pen name of an expert in Latin American affairs"),

2 worldview 